\title{
A Comparative Study of First and Third Year Prospective Elementary Teachers' Attitude Towards Technology-Based Mathematics Assessment
}

\author{
Desri Rahmadhani ${ }^{1}$, Zetra Hainul Putra ${ }^{* 2}$, Eddy Noviana ${ }^{3}$ \\ DOI: $10.35445 /$ alishlah.v13i1. 488
}

Article Info

Keywords:

Attitude

Mathematics

Assessment

Technology

Kata kunci:

Sikap

Penilaian Matematika

Teknologi

\section{Abstract}

This study aims to determine how prospective elementary teachers' attitudes about technology-based mathematics assessment determine whether there are attitude differences between first and third-year prospective elementary teachers about technology-based mathematics assessment. This research is a comparative study with quantitative methods. The research data was conducted through an online survey, namely a questionnaire using Google Form. The populations of this study were 236 prospective elementary teachers with a sample size of 70 prospective elementary teachers. We use the proportion stratified random sampling technique to select the sample of this study. The results showed that the prospective elementary teachers have good attitudes toward technology-based mathematics assessment. This study also shows no difference between first and third-year prospective elementary teachers' attitudes towards the technology-based mathematics assessment.

\begin{abstract}
Abstrak
Penelitian ini bertujuan untuk mengetahui bagaimana sikap calon guru sekolah dasar terhadap asesmen matematika berbasis teknologi dan untuk mengetahui ada tidaknya perbedaan sikap antara calon guru sekolah dasar tahun pertama dan tahun ketiga. Penelitian ini merupakan penelitian komparatif dengan metode kuantitatif. Pengumpulan data penelitian dilakukan melalui survei online yaitu kuisioner dengan menggunakan Google Form. Populasi penelitian ini sebanyak 236 calon guru sekolah dasar dengan jumlah sampel 70 orang. Kami menggunakan teknik proportionate stratified random untuk memilih sampel penelitian ini. Hasil penelitian menunjukkan bahwa calon guru sekolah dasar memiliki sikap yang baik terhadap asesmen matematika berbasis teknologi. Penelitian ini juga menunjukkan bahwa tidak ada perbedaan antara sikap calon guru sekolah dasar pertama dan ketiga terhadap pembelajaran matematika berbasis teknologi.
\end{abstract}

\section{INTRODUCTION}

Globalization's development is progressing so rapidly, including in the era of the industrial revolution 4.0 as it is today. All things in life are inseparable from advances in information

\footnotetext{
${ }^{1}$ Universitas Riau, Pekanbaru, Indonesia

Email: desri.rahmadhanio938@student.unri.ac.id

${ }^{2}$ Universitas Riau, Pekanbaru, Indonesia

*Email: zetra.hainul.putra@lecturer.unri.ac.id

${ }^{3}$ Universitas Riau, Pekanbaru, Indonesia

Email: eddy.noviana@lecturer.unri.ac.id
} 
technology because all the supporting components of human life have changed from conventional forms towards digitalization through information technology. Information technology has also penetrated explicitly into various education matters, starting from preparing learning devices, implementing the learning process, and evaluating learning (Adiarta \& Divayana, 2019). Therefore, prospective teachers should have mature readiness to face technology-based learning in line with the times.

Students of teacher education study programs are prospective teachers who will have a role as teachers in elementary schools, including mathematics learning. Mathematics is an essential subject and is often considered demanding for students to understand (Wahyudin in Nurqolbiah, 2016). Mathematics learning has a very close relationship with the assessment or assessment of mathematics learning processes and outcomes, where an assessment has the potential to become a lever to improve the quality of mathematics learning and become a tool for systemic innovation (Asmana, 2018). In its implementation, following technological developments and advances, even the current Covid-19 pandemic, the assessment is applied based on technology or remote assessment, which is possible and easy, especially with an internet network (Ahmad, 2020).

Learning mathematics in the classroom is exceedingly determined from a teacher's perspective and belief in mathematics because imperfections in understanding mathematics from a teacher will more or less cause imperfections in the learning process in the classroom, which can affect students (Fajar in Harsa, 2016). Prospective elementary school teachers and teachers lack knowledge of mathematics (Putra, 2019) and science. They have opposing beliefs in mathematics and science, resulting in anxiety and bad attitudes such as reluctance or doubt in teaching these disciplines (Bursal, 2010). Besides, elementary school teachers' negative attitudes towards mathematics and sciences have a negative impact on teaching beliefs in mathematics and other sciences, thus leading to ineffective instructional instruction (Bursal, 2010). One factor forming teacher attitudes can be seen in the teacher's experience (Avramidis \& Kalyva, 2007).

This research is motivated by previous research results, namely a study conducted by Dogan (2010), which shows that most teachers do not like computer-based activities because they rarely use computers in mathematics courses. Although many teachers believe that computers are an essential component of student education, their lack of knowledge and experience leads to a lack of confidence in their efforts to introduce technology into teaching. This lack of self-confidence leads to anxiety and reluctance to use technology. Attitudes towards technology-based mathematics assessment tend to act, think, perceive, and feel in dealing with objects, ideas, or ideas (Sobur in Farida, 2014). Besides, attitude is an essential initial condition in an activity because there is a strong tendency to pay attention and take action following his wishes (Suharnan in Farida, 2014).

An attitude has three components, namely: a) Cognition components are a form of components that have a relationship with beliefs, ideas, and concepts; b) The affection component is a component related to a person's emotional life; c) The conation component is a component in the form of a tendency to behave (Rhodes \& Courneya, 2003). Sulistyani and Retnawati (2015), using an attitude component based on multidimensional aspects, explain three components: emotional response, beliefs about the subject, tendencies in behaviour related to the subject. The study used several attitude scale instruments, namely Likert with indicators/items divided into three dimensions/domains to measure attitudes. Attitudes about beliefs are included in the cognitive dimension, attitudes about emotional responses are included in the affective dimension, and attitudes about behavioural tendencies are formed in the active dimension.

In this study, we use the attitude component as an instrument in making attitude indicators, namely: a) Cognition is the belief that prospective teachers use technology in mathematics assessment, ideas in choosing and using technology in mathematics assessment, the use of technology and its effect on mathematics assessment; b) Affection becomes the feeling of prospective 
teachers towards technology-based mathematics assessment; c) Conation is a tendency for prospective elementary school teachers to assess mathematics.

Attitude towards mathematics is an essential factor in learning mathematics. Attitudes towards mathematics as a form of liking or disliking mathematics, the tendency to be actively involved or avoid mathematical activities, the belief that someone is good at mathematics or not, and the belief that mathematics has benefits or not (Kusaeri \& Cahyan, 2016). Like attitudes towards mathematics assessment, mathematics assessment results from obtaining data or information about a student's abilities and obstacles. It needs to learn mathematics as a reference to compile a learning program (Astuti \& Novianti, 2017). So the attitude towards mathematics assessment tends to respond well or poorly in the implementation of mathematics assessment, which is an action, thought, or behaviour towards mathematics assessment.

In the application and use of technology, someone tends to respond to good or bad technology, and a good response looks like the way someone uses and applies technology. A negative response is seen when someone stays away or even dislikes technology; this explanation of the attitude towards technology is a form of response to one's reaction to technology.

Based on the explanation above, it can be concluded that the attitude towards technologybased mathematics assessment is a tendency for a person to respond and respond positively and negatively, which is manifested in the form of feelings, actions, behaviour, and thoughts regarding technology-based assessments. The teacher's attitude towards technology is a form of the teacher's tendency to behave in responding/reacting to technology. This response/reaction takes the form of liking or disliking the use and application of technology. A study conducted by Erguvan (in Sudiran, 2015) shows that the successful application of information technology such as the internet into education is highly dependent on the teacher's attitude, which ultimately determines how they use technology in the classroom.

A positive teacher attitude is essential to encourage a student to learn an object. Thus, attitude and awareness are some of the best ways to reach out to computer use. Attitudes and beliefs and high efficacy can help increase proficiency in implementing ICT in the learning process (Zulkifli \& Maznah in Chung, 2010). Teachers with positive attitudes tend to carry out and apply technology-based assessments such as online-based assessments. In contrast, teachers with negative attitudes tend to stay away from the use and application of technology.

\section{METHODS}

This study used comparative research based on a quantitative approach. Comparative research aims to determine the similarities and differences between two or more research subjects (Ananda \& Fadhli, 2018). This study's population was 236 first and third-year student teachers from an elementary teacher institution, a public university, in Riau province, Indonesia. This study's sample was taken using the proportionate stratified random sampling technique, where students were taken randomly in each class. To determine the number of samples in this study, we use the Yamane formula and the formula for looking for samples per class (Sugiyono, 2019) with a sample error rate of $10 \%$ so that the overall sample is 70 participants, while the sample for the third year generation is 34 participants and 36 participants for the first year batch. Data in this study were taken from students who filled out attitude questionnaires using a google form, which is distributed online. The scale used in measuring this instrument is the Likert scale.

In this instrument, the measured attitude variable is seen in the three components of attitude and translated into several indicators of attitude variables. There are two types of statements, namely positive statements and negative statements. Before the questionnaire was distributed online to respondents, the researcher conducted a validity test through Expert Judgment. After testing the validity of the questionnaire, there are 30 valid item statements. Furthermore, the researcher conducted a reliability test. The research instrument on the attitude variable of the third and firstyear batches of teacher candidates had a high-reliability level of 0.761 and 0.858 . 
The data analysis technique in this study is to use statistics with the following stages: (a) data scaling (b) Sorting data from smallest to largest (c) Calculating range or range (r) (d) Determining the mean and standard deviation (standard deviation) (e) Determine the category of attitudes of prospective elementary school teachers by using categories, namely very agree/excellent, agree/good, disagree/sufficient, strongly disagree/less adapted from research conducted by Putra, Witri, and Yulita (2019).

Table 1 Determination of Attitude Categories

\begin{tabular}{l|l}
\hline Interval & Category \\
\hline $3.26-4.00$ & Very Agree/Very Good \\
$2.51-3.25$ & Agree/Good \\
$1.76-2.50$ & Disagree/Enough \\
$1.00-1.75$ & Strongly Disagree/Less \\
\hline
\end{tabular}

The analysis prerequisite tests were carried out: (a) Normality test, normality test using the Kolmogorov Smirnov technique with SPSS 20. The normality test results is obtained by Asymp. Sig. (2-tailed) in the attitude variable of the third year generation, namely $0.200>0.05$ and the attitude variable of the first-year generation, namely $0.000<0.05$, then the attitude variable data for the third year generation is normally distributed while the attitude variable data for the first year generation is not normally distributed. (b) Asymp obtains homogeneity test, the results of the homogeneity test. Sig. (2-tailed), namely 0.155> 0.05. The two groups were also homogeneous.

\section{FINDINGS AND DISCUSSION}

\section{Attitudes of first and third year prospective elementary teachers towards technology-based mathematics assessment}

The attitude variable consists of 5 indicators, and then from each indicator, a statement item is made. The results of a questionnaire on the attitudes of prospective elementary school teachers in the third year of the first year in each indicator are as follows:

1) The score for the indicators of confidence in prospective teachers using technology in mathematics assessment (Cognition)

Figure 1 presents the questionnaire results on the attitudes of the first and third-year prospective elementary teachers. In general, the indicators for the confidence of prospective teachers using technology in the mathematics assessment of the third year batch of teacher candidates have an attitude categorized as good with an average overall statement of 2.59. The prospective teacher of the first-year class has an attitude that is categorized as good with an average overall statement of 2.52. Among the eight statements above, the highest in statement 5 is about using technology to improve performance and self-effectiveness. Third-year teacher candidates have an average of 3.5, while the first generation teacher candidates have an average of 3.53. The lowest statement is in statement 8; namely, the successful application of technology in elementary schools requires support from various parties. The third-year class teacher candidates have an average of 1.32, while the firstyear generation teacher candidates have an average of 1.31 . 


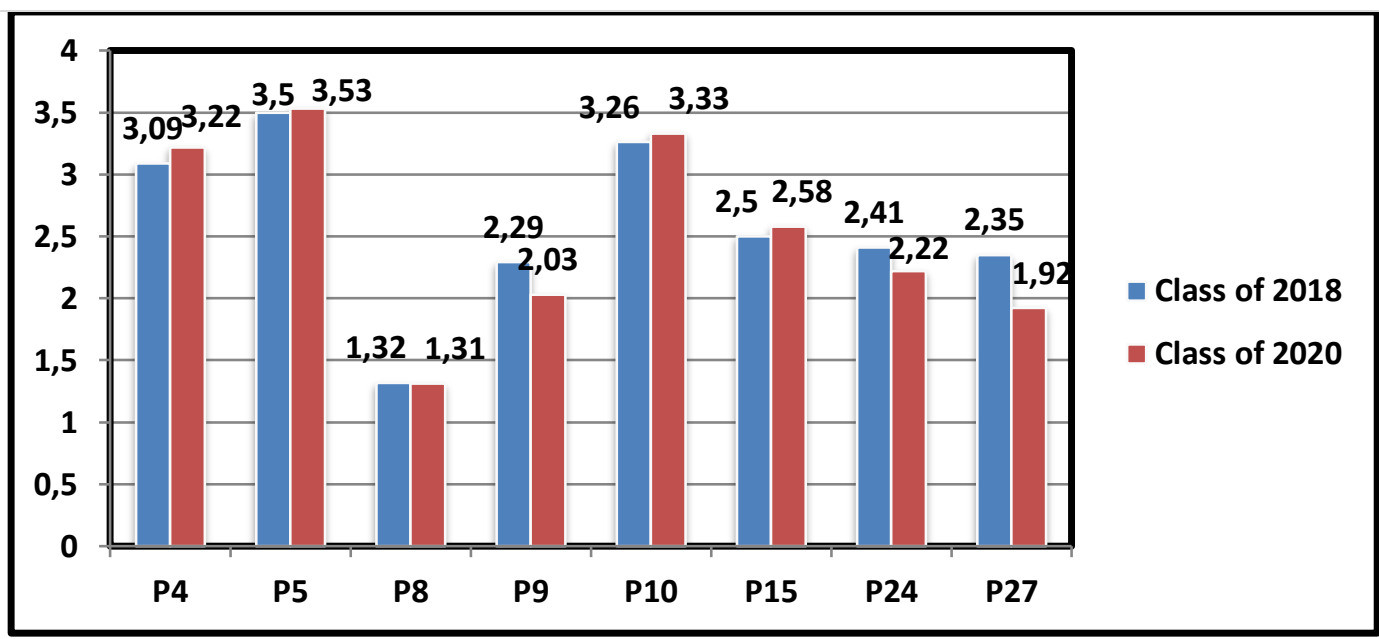

Figure 1. Indicator Score of Confidence in Teacher Candidates Using Technology in Mathematics Assessment (Cognition)

Based on Figure 1, although the overall attitude of the third generation teacher candidates to the first batch in the first indicator is categorized as good but it is declared insignificant. It can be seen in the 8 statements above that there is 1 statement that is categorized as deficient, 3 statements are categorized as sufficient and 1 statement which has different categories, namely good and quiet.

2) Score indicators of ideas in selecting and using technology in mathematics assessment (Cognition)

Figure 2 presents the results of the questionnaire on the attitudes of the third and first batch teachers. In general, the indicator of ideas in choosing and using technology in mathematics assessment of prospective teachers has a good attitude in the third generation with an average overall statement of 2.96 and the prospective teacher of the first generation with an average overall statement of 2.97. Among the four statements above, the highest in statement 23 is that mathematics assessment can be carried out using several online game-based applications such as Quizizz and Kahoot. Third-generation teacher candidates have an average of 3.32. In contrast, the first generation teacher candidates have an average of 3.36. The lowest statement is in statement 12; a formative mathematical assessment such as self-assessment cannot be done using technology. Third-generation teacher candidates have an average of 2.38 , while first-generation teacher candidates have an average of 2.14 .

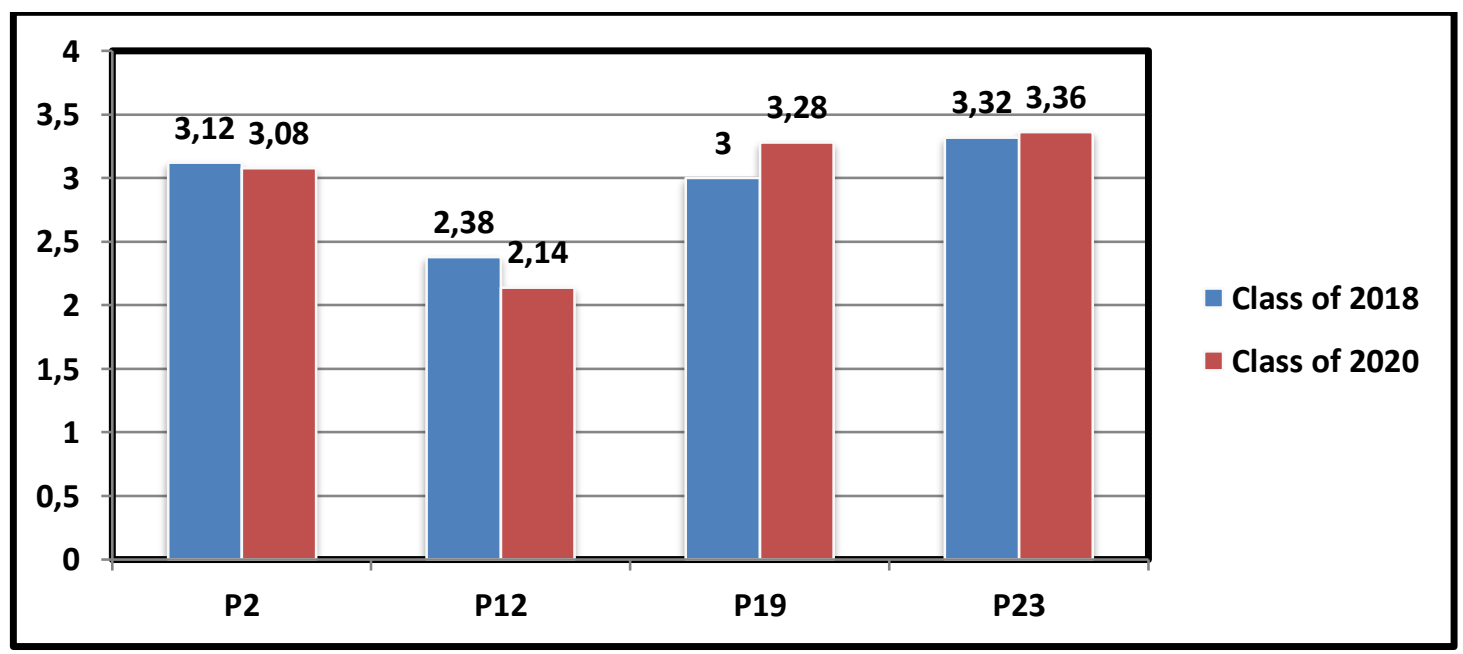

Figure 2. Score Indicator of Ideas in Choosing and Using Technology in Mathematical Assessment (Cognition) 


\section{3) The score of technology use indicators and their effect on mathematics assessment (Cognition)}

Figure 3 presents the results of the questionnaire on the attitudes of the third and first batch teachers. In general, the indicators of the use of technology and its effect on the assessment of mathematics, prospective teachers have an attitude that is categorized as good / agree in the third generation with an average overall statement of 2.94 and prospective teachers of the first generation with an average overall statement of 2.76. Among the eight statements above, the highest statement is in statement 14; namely, the technology-based assessment is more efficient in terms of time. Third generation teacher candidates have an average of 3.35, while the first teacher candidates have an average of 3.31. The lowest statement for the third generation of teacher candidates in statement 17 is that I cannot carry out a technology-based mathematics assessment with an average of 2.68. In contrast, for the first generation teacher candidates in statement 29, the implementation of technology-based assessments makes students lazier by an average of 2.17.

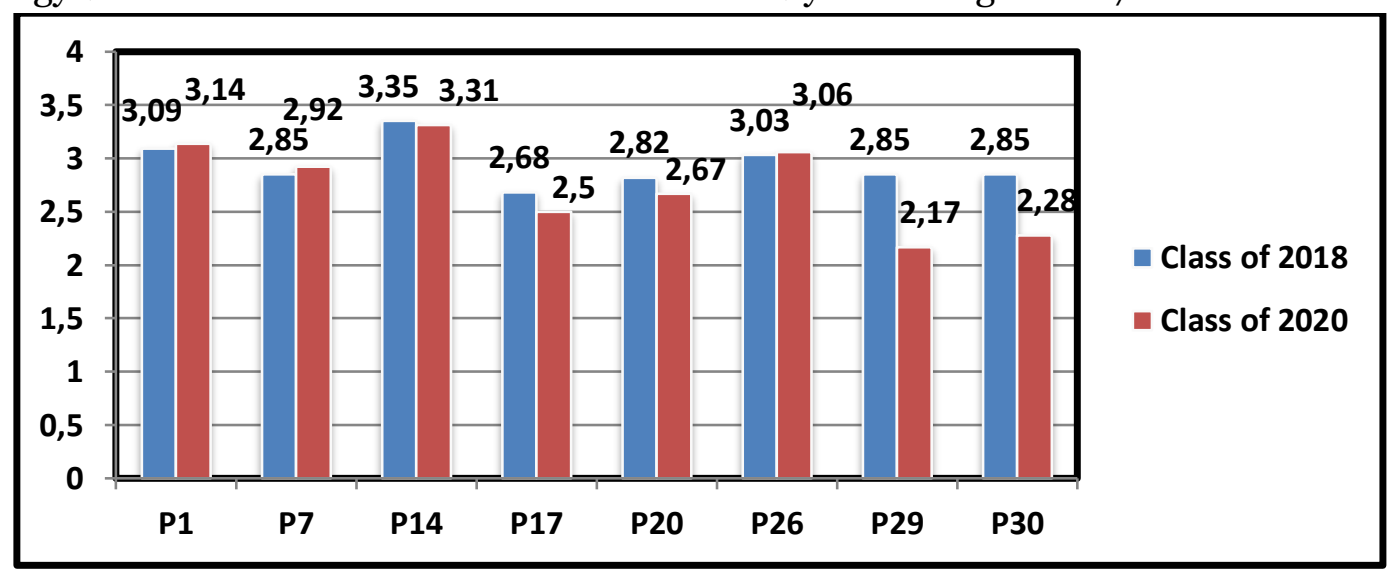

Figure 3. Scores of Technology Use Indicators and Their Effects on Mathematics Assessment (Cognition)

Based on Figure 3, although overall it is categorized as good 3 statements have differences based on the average attitude statement of the third generation of teacher candidates to the first generation. In statement 17, it is categorized as good in the third generation with an average of 2.68, while in the first generation it is categorized as sufficient with an average of 2.5. Statement 29 is categorized as good in the third generation with an average of 2.85 while in the first generation it is categorized as sufficient with an average of 2.17. Statement 30 is categorized as good in the third generation with an average of 2.85 , while in the first generation, it is categorized as sufficient with an average of 2.28 .

4) The score of the prospective teacher's feelings towards technology-based mathematics assessment (affection)

Figure 4 presents the results of the questionnaire on the attitudes of the third and first batch teachers. In general, the indicators of the feeling of the prospective teachers towards the technologybased mathematics assessment of the prospective teachers have an attitude that is categorized as good / agree in the third generation with an average overall statement of 2.92 and the prospective teacher of the first generation with an average overall statement of 2.81. Among the 5 statements above, the highest statement for the third generation of teacher candidates in statement 21, namely the use of technology in mathematics assessment, motivated me to teach with an average of 3.09. In contrast, for the first generation, teacher candidates in statement 28, technology-based mathematics were more interesting and fun for students with an average of 3.08. The lowest statement for the third generation and -generation teacher candidates in statement 18 is that this technology makes children nervous in completing assignments. The average third-generation teacher candidates are 2.59, and the average first-generation teacher candidates 2.36 . 


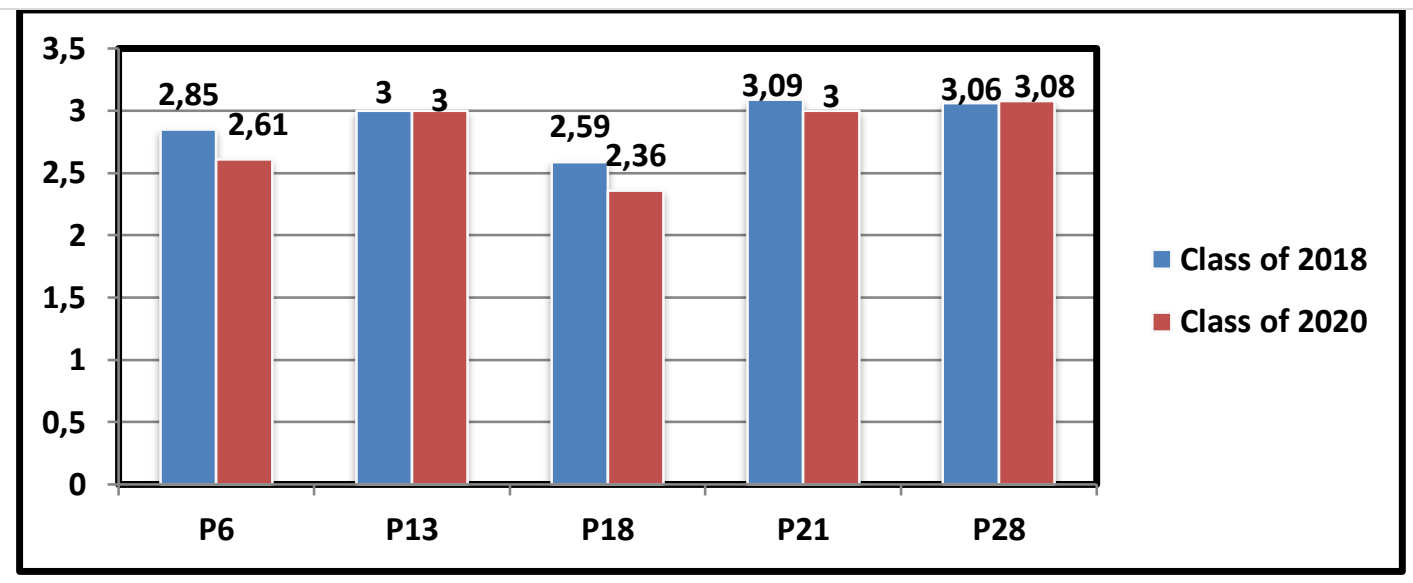

Figure 4. Indicator Scores of Prospective Teachers' Feelings of Technology-Based Mathematics Assessment (Affection)

Based on Figure 4, although overall it is categorized as good, there is 1 statement that has a difference based on the average statement of the attitudes of the third generation of teacher candidates to the first generation. In statement 18, it is categorized as good in the third generation with an average of 2.59, while in the first generation it is categorized as sufficient with an average of 2.36 .

5) The score of the predisposition indicator of prospective elementary school teachers towards mathematics assessment (Conation)

Figure 5 presents the questionnaire results on the attitude of the third generation teacher with the first generation. In general, the trend indicators for primary school teacher candidates for the assessment of mathematics for the third generation of teacher candidates have an attitude that is categorized as good with an average overall statement of 2.83 and that for the first generation teacher candidates have an attitude that is categorized as good with an average overall statement of 2.63. Among the 5 statements above, the highest is in statement 3, namely, this technology-based assessment can present images, which is more interesting in math problems. Third generation teacher candidates have an average of 3.38, while the first teacher candidates have an average of 3.31. The lowest statement is in statement 25; this technology-based assessment makes it more difficult for students to analyze pictures and facts about concepts and procedures because there is no direct teacher presence. Third generation teacher candidates have an average of 2.35, while the first teacher candidates have an average of 1.89.

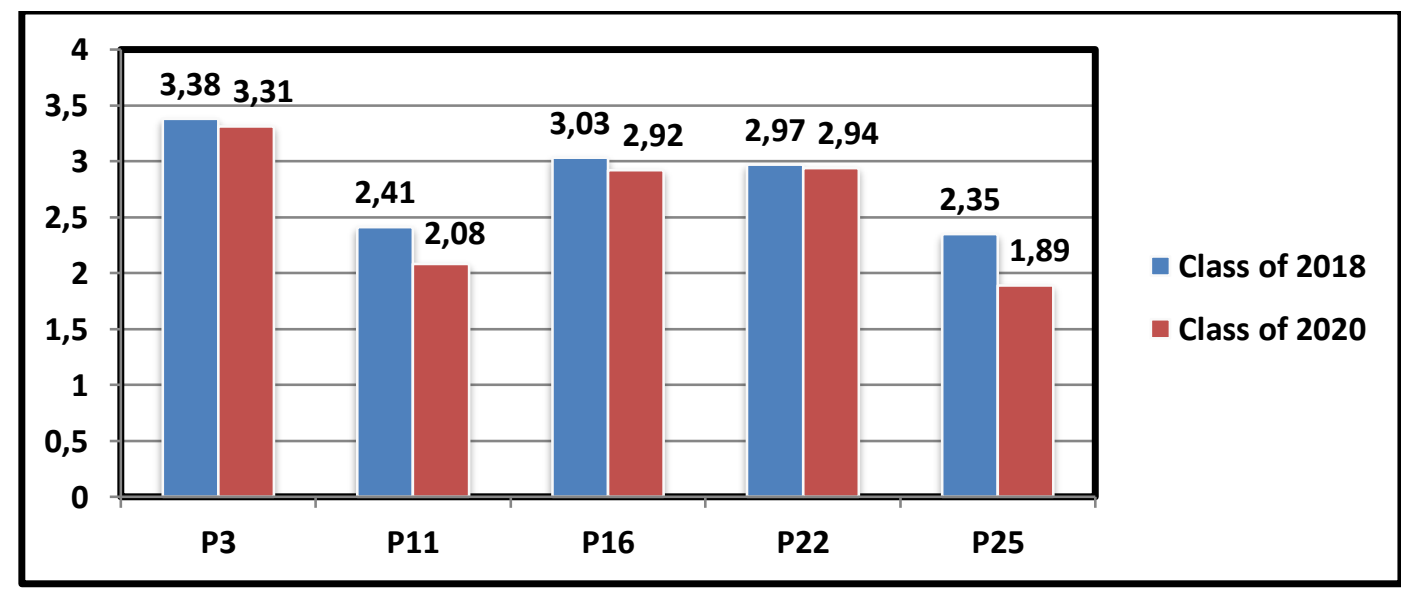

Figure 5. Indicator Score of Tendency of Prospective Primary School Teachers to Mathematics Assessment (Konasi)

Based on Figure 5, although overall, it is categorized as good, there are 2 statements of attitudes of prospective teachers categorized as sufficient. Statement 11 "I feel that implementing 
manual mathematics assessment is better than using technology" is categorized as sufficient, with an average of 2.41 in the third generation and 2.08 in the first generation. Statement 25, "I feel that accessing technology applications take longer" is categorized as sufficient, with an average of 2.35 in the third batch and 1.89 in the first batch.

\section{Comparative Hypothesis Testing}

1) The Mann-Whitney Hypothesis Test to Compare First and Third Years Students' Attitudes

Hypothesis testing is done to determine whether the hypothesis that has been proposed in this study is accepted or rejected. Hypothesis testing in this study uses the Mann-Whitney hypothesis test.

The Mann-Whitney hypothesis test aims to determine whether there are differences in the attitudes of the third-year class and first-year teacher candidates towards technology-based mathematics assessment. This study using the Mann-Whitney test using SPSS version 20. The results of the Mann-Whitney test using SPSS version 20 can be seen in Table 2 below:

Table 2. The Mann-Whitney Test Results on First and Third Year Students' Attitudes

\begin{tabular}{ll}
\hline Interval & Results \\
\hline Mann-Whitney U & 471.000 \\
Wilcoxon W & 1066.000 \\
Z & -1.660 \\
Asymp. Sig. (2-tailed) & .097 \\
\hline
\end{tabular}

Based on table 2, the results of the Mann-Whitney test with the help of SPSS version 20 obtained the Asymp results. Sig. (2-tailed) is 0.097. It means Asymp. Sig. (2-tailed)> 0.05, which means no difference in the attitudes between first and third-year prospective elementary teachers towards the technology-based assessment. So it can be concluded, "the hypothesis is rejected". Thus, there is no difference in the attitudes of prospective elementary school teachers from the third year and the first-year class.

\section{2) Mann-Whitney Test for Attitude Components}

Table 3 presents the result of Mann-Whitney tests based on the attitude components. The tests were conducting the differences between first and third-year students teachers' attitude components.

Table 3. Mann-Whitney Test Results based on Attitude Components

\begin{tabular}{llll}
\hline Component & Asymp. Sig. (2-tailed) & Circumstances & Decision \\
\hline Cognition & 0.071 & Significance $>0.05$ & Hypothesis is rejected \\
Affection & 0.333 & Significance $>0.05$ & Hypothesis is rejected \\
Konasi & 0.266 & Significance $>0.05$ & Hypothesis is rejected \\
\hline
\end{tabular}

Based on table 3, the results of the Mann-Whitney test with the help of SPSS version 20 obtained the Asymp results. Sig. (2-tailed) attitude component, namely Asymp. Sig. (2-tailed)> 0.05, which means that there is no difference in the three components of the attitudes of the third year class of elementary school teacher candidates with the first year of the technology-based assessment.

\section{3) Mann-Whitney Test for Attitude Indicator of Third Year Class of Elementary School Teacher Candidates with First-Year Class}

Table 4 presents the result of Mann-Whitney tests based on the attitude indicators. The tests were conducted to investigate the differences between first and third-year students teachers' attitude indicators. 
Table 4. Mann-Whitney Test Results based on Indicators of Attitude

\begin{tabular}{llll}
\hline Component & Asymp. Sig. (2-tailed) & Circumstances & Decision \\
\hline First & 0.181 & Significance $>0.05$ & Hypothesis is rejected \\
Second & 0.192 & Significance $>0.05$ & Hypothesis is rejected \\
Third & 0.026 & Significance $<0.05$ & Hypothesis accepted \\
Fourth & 0.333 & Significance $>0.05$ & Hypothesis is rejected \\
Fifth & 0.266 & Significance $>0.05$ & Hypothesis is rejected \\
\hline
\end{tabular}

Based on table 4, the Mann-Whitney test results, with the help of SPSS version 20 obtained the first, second, fourth and fifth indicators obtained by Asymp. Sig. (2-tailed)> 0.05, which means that there is no significant difference between the attitudes of the third-year class of elementary school teacher candidates and the first-year class towards technology-based assessment. Meanwhile, the third indicator obtained Asymp. Sig. (2-tailed) <0.05, which means a significant difference between the attitudes of the third-year class of elementary school teacher candidates and the firstyear class towards technology-based assessment.

Based on the results of the research on the variable attitudes of the third year class of elementary school teacher candidates with the first year of the 70 research samples, in general, an overall average of 2.85 third-year class teacher candidates and 2.74 first-year class teacher candidates had good attitudes towards mathematics-based assessment technology. Based on the average attitudes of the third year and first year batches of teacher candidates, the highest attitude regarding technology-based mathematics assessment is that of the third-year class with an average of 2.85. Meanwhile, based on the third-year teacher candidates' attitude category with the first firstyear class, the same category, namely good / agree with technology-based mathematics assessment. Prospective elementary school teachers for the third and first-year batches have a positive attitude towards technology-based mathematics assessment. The results of the study regarding the positive attitudes of the third and first-year batches of teacher candidates are in line with the research (Dogan, 2010), which found that trainee teachers generally have a positive attitude towards computer use in mathematics by expressing their positive feelings about computers and information technology.

Based on the comparative hypothesis test results, Ha rejected, and Ho accepted the results, which means that the attitude of the prospective teacher of the third generation with the first generation is not different. It can be stated that the attitudes of the third year and the first year batch of teacher candidates have the same attitude towards technology-based mathematics assessment, namely in the attitude analysis which states that the attitudes of the third year teacher candidates with the first year class are categorized the same as an average of 2.85 and 2.74 which is good / agree in technology-based mathematics assessment. There is no influence on prospective teachers' attitudes towards technology-based mathematics assessment based on their learning experiences. The level of the learning experience is in a short time interval between the third generation (2018) and the first generation (2020). Technology does not always affect prospective teachers' attitudes and does not change the attitudes of prospective teachers in the short time between the third generation (2018) and the first generation (2020).

This batch of prospective teachers has an interval of two years because attitudes have not changed or been the same about technology. The results of this study are in line with Lestari (2015), which states that along with the progress of the development of information and communication technology, most of the teachers do not seem to be accustomed to using computers, in addition to the understanding or perceptions and positive attitudes of teachers towards ICT which are relatively uneven and adequate. This is also in line with Garofalo's opinion in Dogan (2010), which states that underlining the fact that teachers' adoption of technology requires professional development that focuses on conceptual and pedagogical problems, continuous support in intensive initial assistance and regular follow-up activities. Based on the explanation above, prospective teachers' attitudes towards technology-based mathematics assessment tend to be stable/the same/unchanged, and their experiences in using technology do not affect attitudes. This is in line with a study conducted by Teo (2011) that the formation of attitudes is through personal experience and several factors in the formation of attitudes, namely personal experience, cultural influences, mass media, educational and religious institutions. 


\section{CONCLUSION}

The results and discussion show that the overall average of 2.85 third-generation teacher candidates and 2.74 first-generation teacher candidates have good attitudes towards technologybased mathematics assessment. Based on the average attitude of the third generation of teacher candidates to the first generation, the highest attitude regarding technology-based mathematics assessment is the third generation, with an average of 2.85. Meanwhile, based on the third generation of teacher candidates' attitude category with the first generation, they are in the same category: good / agree with technology-based mathematics assessment. Prospective elementary school teachers of the third and first batches have an excellent/agreeable attitude, which means a positive attitude towards technology-based mathematics assessment.

Based on the results of the comparative hypothesis test that has been carried out between the attitude variables of the third generation of teacher candidates and the first generation, it shows that the value of the comparison of the variable attitudes of the third generation of teacher candidates to the first generation is known to Asymp. Sig. (2-tailed)> 0.05, namely, 0.097> 0.05, which means that the two variables of the third generation teacher candidates' attitude and the first batch did not significantly differ.

This study recommends that students as teacher candidates must improve their positive attitudes towards technology-based mathematics assessment; if seen from the results of the research, the attitudes of prospective teachers are still in the good/low category of agreeing to technology-based mathematics assessment, so a better attitude is needed because of their attitude. Positive ones will produce a positive tendency in responding/reacting in the form of actions, thinking and so on in technology-based mathematical assessments.

\section{ACKNOWLEDGMENT}

The authors would like to thank RISTEKBRIN and LPPM Universitas Riau for funding this research under the DRPM research grant number 469/UN.19.5.1.3/PT.01.03/2021.

\section{REFERENCES}

Adiarta, A., \& Divayana, D. G. H. (2019). Pengembangan soal test digital matakuliah asesmen dan evaluasi menggunakan aplikasi wondershare. Jurnal Pendidikan Teknologi Dan Kejuruan, 16(2), 287. https://doi.org/10.23887/jptk-undiksha.v16i2.19199

Ahmad, I. F. (2020). Asesmen alternatif dalam pembelajaran jarak jauh pada masa darurat penyebaran coronavirus disease (covid-19) di indonesia. PEDAGOGIK: Jurnal Pendidikan, 7(1), 195-222. https://doi.org/10.33650/pjp.v7i1.1136

Ananda, R., \& Fadhli, M. (2018). Statistik Pendidikan. Medan: CV. Widya Puspita.

Asmana, A. T. (2018). Pengembangan Rubrik Analitik untuk Asesmen Komunikasi Matematika Tertulis dalam Pemecahan Masalah Matematika. Jurnal Elektronik Pembelajaran Matematika, 5(1), 64-77.

Astuti, E. Y., \& Novianti, R. (2017). Asesmen Kesulitas Belajar Matematika di Kelas 1 SDN Sukarasa Kota Bandung. Journal of Special Education, 3(1), 31-39. https://doi.org/http://dx.doi.org/10.30999/jse.v3i1.150

Avramidis, E., \& Kalyva, E. (2007). The influence of teaching experience and professional development on Greek teachers' attitudes towards inclusion. European Journal of Special Needs Education, 22(4), 367-389. https://doi.org/10.1080/08856250701649989

Bursal, M. (2010). Turkish preservice elementary teachers' self-efficacy beliefs regarding mathematics and science teaching. International Journal of Science and Mathematics Education, 8(4), 649-666. https://doi.org/10.1007/s10763-009-9179-6

Chung, H. (2010). Sikap Guru Bahasa Melayu terhadap Penggunaan Teknologi Maklumat dan Komunikasi (ICT) Dalam Pengajaran di Sekolah-sekolah Rendah di Bintulu, Sarawak. Jurnal Pendidikan Malaysia, 35(1), 59-65.

Dogan, M. (2010). Primary Trainee Teachers' Attitudes to and use of computer and Technology in Mathematics: The Case of Turkey. Educational Research and Review, 5(11), 690-702. 
https://doi.org/https://doi.org/10.5897/ERR.9000265

Farida, N. (2014). Pengaruh sikap kreatif terhadap prestasi belajar matematika. AKSIOMA: Journal of Mathematics Education, 3(2), 10-15. https://doi.org/10.24127/ajpm.v3i2.77

Harsa, F. S. (2016). Integrasi ICT dalam pembelajaran matematika. Journal Paedagogi, 8(2), 158162. https://doi.org/https://doi.org/10.1234/paedagogi.v8i2.8165

Kusaeri, \& Cahyan, E. D. H. (2016). Sikap, Harapan, dan Persepsi Siswa pada Matematika serta Implikasinya terhadap Kemampuan Regulasi Diri. Jurnal Pengajaran MIPA, 21(2), 114-121.

Lestari, S. (2015). Faktor-faktor yang mempengaruhi pemanfaatan TIK oleh guru. Jurnal Kwangsan, 3(2), 121. https://doi.org/10.3180o/jtp.kw.v3n2.p121--134

Nurqolbiah, S. (2016). Peningkatan Kemampuan Pemecahan Masalah, Berpikir Kreatif dan SelfConfidence Siswa Melalui Model Pembelajaran Berbasis Masalah. Jurnal Penelitian Pendidikan Dan Pengajaran Matematika, 2(2), 143-158. https://doi.org/https://doi.org/10.37058/jp3m.v2i2.166

Putra, Z. H, Witri, G., \& Yulita, T. (2019). Development of powerpoint-based learning media in integrated thematic instruction of elementary school. International Journal of Scientific and Technology Research, 8(10), 697-702.

Putra, Z. H. (2019). Elementary teachers' knowledge on fraction multiplication: An anthropological theory of the didactic approach. Journal of Teaching and Learning in Elementary Education, 2(1), 47-52. https://doi.org/http://dx.doi.org/10.33578/jtlee.v2i1.6964

Rhodes, R. E., \& Courneya, K. S. (2003). Investigating multiple components of attitude, subjective norm, and perceived control: An examination of the theory of planned behaviour in the exercise domain. British Journal of Social Psychology, 42(1), 129-146. https://doi.org/10.1348/014466603763276162

Sudiran. (2015). Sikap Guru dan Tingkat Penggunaan Teknologi Informasi dan Komunikasi di Kelas Sebagai Media Pembelajaran Bahasa Inggris di SMA 3 dan SMK 1 Muhammadiyah Kota Batu. Jurnal Inovasi Pembelajaran, 1(1), 98-112.

Sugiyono. (2019). Metode Penelitian Pendidikan. Bandung: Alfabeta.

Sulistyani, N., \& Retnawati, H. (2015). Pengembangan perangkat pembelajaran bangun ruang di SMP dengan pendekatan problem-based learning. Jurnal Riset Pendidikan Matematika, 2(2), 197. https://doi.org/10.21831/jrpm.v2i2.7334

Teo, T. (2011). Factors influencing teachers' intention to use technology: Model development and test. Computers \& Education, 57(4), 2432-2440. Retrieved from https://www.learntechlib.org/p/50809/ 